AIR WAR COLLEGE

AIR UNIVERSITY

\title{
THE CIVIL-MILITARY GAP AND WOMEN IN COMBAT: THE ELITE'S ATTITUDE TRANSFORMATION, 1991-2013
}

\author{
by \\ Charles G. Ohliger, Col, USAF \\ A Research Report Submitted to the Faculty \\ In Partial Fulfillment of the Graduation Requirements \\ Advisor: Dr. Jacqueline E. Whitt
}

12 February 2015 


\section{Report Documentation Page}

Public reporting burden for the collection of information is estimated to average 1 hour per response, including the time for reviewing instructions, searching existing data sources, gathering and maintaining the data needed, and completing and reviewing the collection of information Send comments regarding this burden estimate or any other aspect of this collection of information,

including suggestions for reducing this burden, to Washington Headquarters Services, Directorate for Information Operations and Reports, 1215 Jefferson Davis Highway, Suite 1204, Arlington

VA 22202-4302 Respondents should be aware that notwithstanding any other provision of law, no person shall be subject to a penalty for failing to comply with a collection of information if it

does not display a currently valid OMB control number

\begin{tabular}{|c|c|c|}
\hline $\begin{array}{l}\text { 1. REPORT DATE } \\
12 \text { FEB } 2015\end{array}$ & 2. REPORT TYPE & $\begin{array}{l}\text { 3. DATES COVERED } \\
\mathbf{0 0 - 0 0 - 2 0 1 5} \text { to 00-00-2015 }\end{array}$ \\
\hline \multirow{3}{*}{\multicolumn{2}{|c|}{$\begin{array}{l}\text { The Civil-Military Gap And Women In Combat: The Elite's Attitude } \\
\text { Transformation, 1991-2013 }\end{array}$}} & 5a. CONTRACT NUMBER \\
\hline & & 5b. GRANT NUMBER \\
\hline & & 5c. PROGRAM ELEMENT NUMBER \\
\hline \multirow{3}{*}{\multicolumn{2}{|c|}{ 6. AUTHOR(S) }} & 5d. PROJECT NUMBER \\
\hline & & 5e. TASK NUMBER \\
\hline & & 5f. WORK UNIT NUMBER \\
\hline \multicolumn{2}{|c|}{$\begin{array}{l}\text { 7. PERFORMING ORGANIZATION NAME(S) AND ADDRESS(ES) } \\
\text { Air War College,Air University,Maxwell AFB,AL }\end{array}$} & $\begin{array}{l}\text { 8. PERFORMING ORGANIZATION } \\
\text { REPORT NUMBER }\end{array}$ \\
\hline \multirow{2}{*}{\multicolumn{2}{|c|}{ 9. SPONSORING/MONITORING AGENCY NAME(S) AND ADDRESS(ES) }} & 10. SPONSOR/MONITOR'S ACRONYM(S) \\
\hline & & $\begin{array}{l}\text { 11. SPONSOR/MONITOR'S REPORT } \\
\text { NUMBER(S) }\end{array}$ \\
\hline
\end{tabular}

12. DISTRIBUTION/AVAILABILITY STATEMENT

Approved for public release; distribution unlimited

13. SUPPLEMENTARY NOTES

14. ABSTRACT

A fundamental concern in the debate about a civil-military gap in the United States is that the space between the values or attitudes of civilian society and the military may become so wide that it threatens civil-military cooperation and military effectiveness. This study sheds light on that concern by examining the attitudes of the civilian and military elite on women in combat, a social issue at the heart of the civil-military gap, as the US regrouped after the Gulf War then fought in Afghanistan and Iraq. The study reveals that by expanding women???s roles in combat, the wars served as a proving ground which illustrated to the civilian and military elite that women???s service had both society???s acceptance and a positive impact on military effectiveness, thereby harmonizing their attitudes.

15. SUBJECT TERMS

16. SECURITY CLASSIFICATION OF:

a REPORT unclassified b ABSTRACT unclassified c THIS PAGE unclassified
17. LIMITATION OF ABSTRACT

Same as Report (SAR)

\begin{tabular}{l|l}
$\begin{array}{c}\text { 18. NUMBER } \\
\text { OF PAGES } \\
\mathbf{3 4}\end{array}$ & 19a. NAME OF \\
& \\
&
\end{tabular}




\section{DISCLAIMER}

The views expressed in this academic research paper are those of the author and do not reflect the official policy or position of the US government, the Department of Defense, or Air University. In accordance with Air Force Instruction 51-303, it is not copyrighted, but is the property of the United States government. 


\section{Biography}

Col Charles G. Ohliger is assigned to the Air War College, Air University, Maxwell AFB, AL. Col Ohliger is a mobility officer and pilot with more than 4,700 hours in the C-17, C-21 and T-37, including over 300 hours in combat. He has leadership experience at the group and squadron level. He has a bachelor's degree in behavioral sciences and two master's degrees, one in human resources development and one in military operational arts and sciences. Col Ohliger is a graduate of the Squadron Officers' School and the Air Command and Staff College, both in residence, at Air University. 


\begin{abstract}
A fundamental concern in the debate about a civil-military gap in the United States is that the space between the values or attitudes of civilian society and the military may become so wide that it threatens civil-military cooperation and military effectiveness. This study sheds light on that concern by examining the attitudes of the civilian and military elite on women in combat, a social issue at the heart of the civil-military gap, as the US regrouped after the Gulf War then fought in Afghanistan and Iraq. The study reveals that by expanding women's roles in combat, the wars served as a proving ground which illustrated to the civilian and military elite that women's service had both society's acceptance and a positive impact on military effectiveness, thereby harmonizing their attitudes.

Although debate on the issue was intense, it is evident the civilian and military elite engaged in frank dialogue on mutual interests to constructively reconcile their differences over time and agreed to favor military effectiveness over social values because national security was at stake. With social values residing at the heart of the civil-military gap, this study suggests that the civil-military gap is neither a chasm nor unbridgeable. The nature of the relations of the civilian and military elite suggests there is no immediate cause for concern.
\end{abstract}




\section{Introduction}

A debate persists in the United States over the significance of a civil-military gap.

According to Peter Feaver, Richard Kohn and Lindsay Cohn, "The [fundamental] concern is that a 'gap' in values or attitudes between people in uniform and civilian society may have become so wide that it threatens the effectiveness of the armed forces and civil-military cooperation." Studies of the civil-military gap often focus on identifying its many features at a single point in time. There are at least two problems with this approach. First, it is difficult to discern which features of the civil-military gap, if any, are threatening. Second, and more crucial, it is difficult to assess how the civil-military gap is changing over time. ${ }^{2}$

This study addresses these problems by identifying and considering one important feature of the civil-military gap over a period of time. Two contemporary and compelling studies conclude that attitude differences between the civilian and military elite on social issues are a pivotal feature of the civil-military gap because they have the potential to significantly impact military effectiveness. ${ }^{3}$ Indeed, a RAND study concluded the elite's perspectives on social

\footnotetext{
${ }^{1}$ Peter D. Feaver, Richard H. Kohn, and Lindsay P. Cohn, "The Gap Between Military and Civilian in the United States in Perspective," in Soldiers and Civilians: The Civil-Military Gap and American National Security (Cambridge, MA: MIT Press, 2001), 1.

${ }^{2}$ One example of these circumstances is Thomas Ricks' article cited at the end of this note. He follows a group of Marines that are reintegrating into society following 11 weeks in boot camp. He illustrates how they experience "reentry shock" because the military's culture is significantly different from society. He raises many concerns about the culture gap and proposes an array of solutions to address the problems. This approach tends to be alarmist and misses the realities of civil-military relations over time. Because he is a respected journalist, his views were taken quite seriously, spawning further studies. Thomas E. Ricks, "The Widening Gap Between Military and Society," The Atlantic, July 1997, http://www.theatlantic.com/magazine/archive/1997/07/the-widening-gap-between-militaryand-society/306158/.

${ }^{3}$ Laura L. Miller and John Allen Williams, "Do Military Policies on Gender and Sexuality Undermine Combat Effectiveness?," in Soldiers and Civilians: The Civil-Military Gap and American National Security (Cambridge, MA: MIT Press, 2001); Triangle Institute for Security Studies, The Civil-Military Gap in the United States: Does It Exist, Why, and Does It Matter?, ed. Thomas S. Szayna (Santa Monica, CA: RAND Corp, 2007). This study uses the term "elite" as a collective noun, referring to the group of persons exercising the major share of authority or influence within a larger group; it is not used as an adjective. Military elite are generally understood to be colonels and general officers. Civilian elite, for purposes of this study are civilian colonel-equivalents or higher; more
} 
issues are the only significant area of divergence linked to military effectiveness. ${ }^{4}$ Interestingly, the RAND study also found that both the civilian and military elite sampled in the study "appear to be significantly more likely to identify with the Republican Party and to assert a more conservative ideology than the population as a whole." ${ }^{5}$ Using the RAND study's conclusions as a point of departure, this study examines the attitudes of the elite on the issue of women in combat (WIC), the first of three social issues cited by RAND. ${ }^{6}$ This study examines WIC from the end of the Gulf War through the wars in Afghanistan and Iraq (1991 to 2013) because significant changes to law and policy regarding women's service occurred during this period. The study's central question is this: How and why have the attitudes of the civilian and military elite changed on WIC during this period, and what are the implications for the civil-military gap? Ultimately, the wars served as a proving ground, illustrating to the civilian and military elite that women serving in ground combat roles had both society's acceptance and a positive impact on military effectiveness, thereby harmonizing their attitudes. This implies the civil-military gap is not currently cause for concern.

\section{Literature}

In The Soldier and the State, Samuel Huntington offered a perspective on civil-military relations that informs civil-military gap understanding. He stated, "The objective... is to develop

specifically, they are primarily elected and appointed officials. Furthermore, civil-military elite considered here are ones that both engage in and influence debate on the issue.

${ }^{4}$ Triangle Institute for Security Studies, The Civil-Military Gap in the United States, 158. Note: There are a number of arguments related to why the military should not be a "social laboratory." Military effectiveness tends to be the strongest argument - the one last to fall. While there are a number of other arguments that are discretely different, this study uses a few of them somewhat interchangeably: security, cohesion, readiness and mission accomplishment all fit under the broader term of effectiveness.

${ }^{5}$ Ibid., 152.

${ }^{6}$ Ibid., xv. This study will use the acronym "WIC" throughout as a space saver and refers to the general condition of women serving in any combat roles. When it is necessary to be more specific, e.g., "ground combat," the study will specifically indicate so. 
a system of civil-military relations which will maximize military security at the least sacrifice of other social values." ${ }^{7}$ Huntington was arguing for primacy of military over civilian concerns when national security is at stake. Social values should be accommodated when there is no security risk. If a gap in social values exists that undermines the balance in civil-military relations, it is the responsibility of society to shift its values toward the military. In contrast, Morris Janowitz, Huntington's contemporary, argued in The Professional Soldier that it is the responsibility of the military to shift toward society if a gap exists in social values. ${ }^{8}$ Huntington continued, "The principal focus of civil-military relations is the relation of the officer corps [military elite] to the state [civilian elite]." ${ }^{\prime 9}$ Huntington also argued that the military elite tended to be comparatively more conservative in their ideology to the civilian elite and possessed a "military mind." 10

In Our Army, Jason Dempsey also offers insight into military officers' ideology: "Very few officers can be described as being consistently conservative on a range of economic and social issues...one finds that the idea that [they] have a distinctly different worldview... conservative and dramatically out of step with the rest of society...is a myth that must be continually debunked." ${ }^{\prime 1}$ However Dempsey discovers that with increasing rank, officers

\footnotetext{
${ }^{7}$ Samuel P. Huntington, The Soldier and the State: The Theory and Politics of Civil-Military Relations (Cambridge: Belknap Press of Harvard University Press, 1957), 2.

${ }^{8}$ Peter Feaver and Richard H. Kohn, Soldiers and Civilians : The Civil-Military Gap and American National Security (Cambridge, MA: MIT Press, 2001), 3; Morris Janowitz, The Professional Soldier, a Social and Political Portrait. (Glencoe, IL: Free Press, 1960).

${ }^{9}$ Huntington, The Soldier and the State, 3.

${ }^{10}$ Ibid., 79. The intent here is not to convey the extent of Huntington's views, but simply to illustrate his general view that the military elite are comparatively conservative which, theoretically, establishes a natural gap in the way of thinking between the civilian and military elite. Furthermore, Janowitz agreed that the military elite were comparatively more conservative.

${ }^{11}$ Jason K. Dempsey, Our Army: Soldiers, Politics, and American Civil-Military Relations (Princeton: Princeton University Press, 2010), 93.
} 
increasingly expressed a Republican affiliation. ${ }^{12}$ He also concluded that the attitudes of Army officers on women's roles correlate strongly with party affiliation. ${ }^{13}$ Synthesizing Dempsey's findings, the military elite tend to reflect Republican attitudes regarding the issue of WIC, creating a gap in attitudes compared to the civilian elite, which are more equally distributed between Republicans and Democrats. ${ }^{14}$ While Dempsey sees the potential for conflict to occur between the civilian and military elite over social issues, he maintains an optimistic view that open and frank dialogue on mutual interests will serve to constructively reconcile differences. ${ }^{15}$ He argues engagement will dissolve "the stereotypes that suggest an unbridgeable gap" between the civilian and military elite, and allow each to "fulfill [their] role in providing for the security and sustained health of our democracy." ${ }^{16}$ Through this dialogue and engagement, the civilian and military elite have the potential to harmonize their attitudes.

\section{The Elite's Attitude Change}

The Gulf War was a watershed event for military women with more than 41,000 deployed, 15 killed and two taken prisoner. ${ }^{17}$ As a result of women's significant role in the Gulf, Representative Patricia Schroeder (D-CO) introduced "a surprise measure" to the House Armed Services Committee (HASC) in 1991, proposing to repeal the 1948 statute prohibiting women's

\footnotetext{
${ }^{12}$ Ibid., 125.

${ }^{13}$ Ibid., 123.

${ }^{14}$ Dempsey's discussion, like Huntington's, is lengthy and nuanced. In many instances he appears contradictory in his findings about military officers' ideology. In fact Dempsey finds that when examining Army officers by rank, they report being Republican or Democrat at a rate roughly equal to the civilian population. This seems to weaken his finding that with increasing rank military officers increasingly express a Republican affiliation. There is no doubt, however, that the theme of both Dempsey's and Huntington's conclusions suggest there is a perceptible degree of collective conservatism in the military elite, no matter how consistent or coherent, to create a natural gap in the thinking between the civilian and military elite as groups.

${ }^{15}$ Dempsey, Our Army, 180.

${ }^{16}$ Ibid., 204-205.

${ }^{17}$ Rosemarie. Skaine, Women in Combat a Reference Handbook (Santa Barbara, CA: ABC-CLIO, 2011), 23, http://ebooks.abc-clio.com/?isbn=9781598844603.
} 
participation in combat aviation. ${ }^{18}$ Schroeder said, "Women have proved themselves in the worst environment and dispelled the myth in this country that they wouldn't be able to handle it.",19

Schroeder's measure quickly passed in a HASC closed session on an unrecorded voice vote and became an amendment to the 1992 National Defense Authorization Act (NDAA). ${ }^{20}$ After the House passed the NDAA, Senators Edward Kennedy (D-MA) and William Roth (RDE) introduced an amendment echoing the House's version. But before the Kennedy-Roth amendment reached a vote, four bipartisan senators offered an amendment to "create a commission to study the legal, military and societal implications of amending the exclusionary laws."21 Senator John McCain (R-AZ) characterized his group's view that the Senate not "rush ahead without proper study and a national consensus. We will be able to make the kind of judgment which will give the American people what they want. We will find the best way to both defend this Nation's national security interests, and provide equality for women in all...military specialties." 22 McCain's statement is salient because it illustrates their attention to balancing the tension between military effectiveness in providing for national security and social values held by society.

18 "Women in Military Combat? What It Means for American Culture and Defense," The Heritage Foundation, May 28, 1991, first paragraph, http://www heritage.org/research/lecture/women-in-military-combat-what-it-meansfor-american-culture-and-defense.

${ }^{19}$ Eric Schmitt, "House Votes Military Budget, Cutting Arms Programs," The New York Times, May 23, 1991, sec. US, last third, http://www.nytimes.com/1991/05/23/us/house-votes-military-budget-cutting-armsprograms html; Alice W. Parham, "Quiet Revolution: Repeal of the Exclusionary Statutes in Combat Aviation What We Have Learned from a Decade of Integration," William \& Mary Journal of Women and the Law 12 (2006 2005): 386. The quote is from Schmitt; Parham indicates that a repeal of the naval exclusion was also discussed but ultimately not acted upon. Schroeder's rationale for choosing combat aviation exclusion as the law to be repealed is not evident, though it is commonly understood women served in non-combat aviation roles and were exposed to general combat conditions.

20 "Women in Military Combat?," first paragraph.

${ }^{21}$ United States. Presidential Commission on the Assignment of Women in the Armed Forces, Report to the President: November 15, 1992: The Presidential Commission on the Assignment of Women in the Armed Forces (Washington, DC: The Commission, 1992), iii.

${ }^{22}$ Ibid. 
The NDAA became law with both amendments. The Kennedy-Roth amendment repealed the combat aviation exclusion and the second amendment formed the Presidential Commission on the Assignment of Women in the Armed Forces. The fact that the NDAA "rocketed through committee with few objections" and with strong bipartisan support suggests the civilian elite were in favor of increasing women's combat role, but that they were proceeding cautiously by creating the Commission. ${ }^{23}$ The New York Times indicated the Department of Defense (DOD) was “neutral," reflecting Secretary of Defense Dick Cheney’s intent to wait for the Commission's findings before making policy changes. ${ }^{24}$

In 1992 the Commission studied women's roles in every major combat function. ${ }^{25} \mathrm{~A}$ majority of the Commission's 15 members (eight civilian and seven military elite) believed "there are circumstances under which women might be assigned combat positions," but "military readiness should be the driving concern." 26 They continued, "Our review of the diverse testimony reveals no thread...that would preclude roles for [WIC]." ${ }^{27}$ However, "the sense of

\footnotetext{
${ }^{23}$ Schmitt, "House Votes Military Budget, Cutting Arms Programs"; US Congress, National Defense Authorization Act for Fiscal Years 1992 and 1993 (1991 - H.R. 2100), 1991, https://www.govtrack.us/congress/bills/102/hr2100. The citation focuses on data found on website shown, not within the bill itself, illustrating the NDAA passed the House with a 76 percent favorable vote; 82 percent of Democrats and 79 percent of Republicans supported the bill. It passed the Senate with a 79 percent favorable vote; 78 percent of Democrats and 91 percent of Republicans supported the bill.

${ }^{24}$ Schmitt, "House Votes Military Budget, Cutting Arms Programs." Cheney did not have a practical opportunity to follow through on this promise. The findings were released on 15 Nov 92, after President Clinton was voted into office. It is evident from the history that Cheney deferred to the incoming defense secretary to make further decisions on the matter.

${ }^{25}$ There is some contention about the objectiveness of this Commission from commission members and in scholarly study. It is evident that the individual committee members, all reflecting attitudes of the elite, were likely not a representative sample. Some commissioners believed the panel was significantly conservative in its composition and that those members served to sway the panel's conclusions. However, the comprehensiveness of the study of the issue and the raw data that emerged is certainly useful and compelling in understanding the history of this issue. "Combat function" means: naval combat, aviation combat, ground combat, etc.

${ }^{26}$ United States. Presidential Commission on the Assignment of Women in the Armed Forces, Report to the President, 22. One of the military officers was a US Army Captain. For purposes of this study, she is considered a member of the elite.

${ }^{27}$ Ibid., 23.
} 
the Commission [was] women should be excluded from direct land combat units" and "effectiveness of ground combat units [is] the most significant criterion." 28

There were notable accusations of bias from a few Commission members. Capt Mary Finch indicated, "Commissioners with...ties to conservative groups had the effect of tipping the results of Commission work against any progress for servicewomen." 29 Regardless, it is clear the commissioners favored concerns of military effectiveness over the uncertain outcome of expanding women's roles because the commissioners lacked compelling evidence. If the Gulf War had lasted longer and afforded the opportunity for women's increased exposure to combat conditions there may have been sufficient compelling evidence to influence more conservative members to alter their attitudes.

The Commission studied the attitudes of the military elite by surveying the entire population of retired general officers, of which 3,224 or 55 percent responded (See Tables $1 \& 2$, Appendix). ${ }^{30}$ The data reveals four observations. First, the extent to which an officer was willing to support WIC was inversely proportional to the directness or closeness of their duty to actual combat conditions; they were most willing to support women in fighter-bomber aircraft and least likely to support women in the infantry. Second, the extent to which an officer was willing to support WIC in any function was directly proportional to how recently he or she retired. This illustrates that their increasing acceptance is likely linked to society's gradual acceptance of gender equality over time. Furthermore, the officers retiring between 1990 and

\footnotetext{
${ }^{28}$ Ibid., 24.

${ }^{29}$ Ibid., 106. Capt Finch's view of some commissioners' decision making as a deliberate, malicious attempt on the part of conservatives may be shortsighted. Based on a review of the individual statements of many dissenting members, it may in fact be an issue of cognitive consistency or cognitive dissonance. That is, their sociocultural values and beliefs were so strong on the subject of WIC that they were unable to accept honest testimony supporting increased women's roles, rationalizing it away as dishonesty on the part of the person testifying.

${ }^{30}$ Ibid., D-7.
} 
1992 showed a significant increase in their willingness to support WIC over the previous group (1985-1989). A possible conclusion is the military elite's increasing approval was the result of witnessing women's capability and women's positive impact on military effectiveness during the Gulf War. ${ }^{31}$ The fourth observation is that a strong majority (approximately 60 percent) of the most recent retirees did not support WIC overall. Fifty-six percent of the responding officers cited a negative impact on unit cohesion as the reason for opposition. ${ }^{32}$ It appears the military elite needed more proof that military effectiveness would not suffer before they would more fully support WIC.

A Roper poll conducted for the Commission revealed the American public's support of WIC was "statistically split.",33 Roper's broad sampling of the military conducted for the commission revealed 57 percent favored current restrictions. ${ }^{34}$ Gallup polls conducted frequently since 1990 indicate it was not until 2005 that a strong majority of the American public (at least two-thirds) consistently supported WIC. ${ }^{35}$

Secretary of Defense Les Aspin reshaped DOD policy on WIC within months of reviewing the Commission's report. He rescinded the Risk Rule, which prohibited women from serving in any support unit that had a similar or greater risk of exposure to combat conditions as a combat unit. He created the Direct Ground Combat Definition and Assignment Rule which, "excluded [women] from assignment to units below the brigade level whose primary mission is

\footnotetext{
${ }^{31}$ There is not sufficient proof to confirm causation. This is one possibility. Certainly there is correlation between their change in attitude and the war.

${ }^{32}$ United States. Presidential Commission on the Assignment of Women in the Armed Forces, Report to the President, D-7.

${ }^{33}$ Ibid., D-1. Forty-seven percent opposed to the current policies restricting women from direct combat while 44 percent were in favor.

${ }^{34}$ Ibid., D-3. Although the military and the American public were surveyed, the Commission did not make an attempt to directly survey the civilian elite's attitudes.

35 Alyssa Brown, “Americans Favor Allowing Women,” Gallup, January 25, 2013, http:/www.gallup.com/poll/160124/americans-favor-allowing-women-combat.aspx.
} 
to engage in direct combat on the ground." ${ }^{36}$ Finally, he asked Congress to rescind the naval combat exclusion. ${ }^{37}$ Aspin's representatives explained the changes stating, "The integration of women into direct ground combat units lacked both congressional and public support" and "would not contribute to the readiness and effectiveness of those units." 38 They also cited "the Department's lack of experience with women in direct ground combat." ${ }^{39}$

In response to Aspin's request, Congress repealed the naval exclusion and enacted into law a requirement that DOD notify Congress 30 days prior to making any changes to policy increasing women's roles. ${ }^{40}$ No further US laws prevented women from serving in combat. ${ }^{41}$ It is apparent the two groups worked together to find common ground that addressed the tension between military effectiveness and society's acceptance of WIC. Although Congress appeared to be more willing to accept WIC than the military elite, the gap between their attitudes appears to have been less characteristic of a chasm and more of a narrow gap.

The wars following the terrorist attacks of 9/11 further influenced the attitude gap between the civilian and military elite. ${ }^{42}$ The US became engaged in two extended combat

${ }^{36}$ Les Aspin, "Direct Ground Combat Definition and Assignment Rule” (Department of Defense, January 13, 1994), http://big.assets huffingtonpost.com/irectGroundCombatDefinitionAndAssignmentRule.pdf.

${ }^{37}$ Parham, “Quiet Revolution,” 389.

${ }^{38}$ US Senate and General Accounting Office, Gender Issues Information on DoD's Assignment Policy and Direct Ground Combat Definition: Report to the Ranking Minority Member, Subcommittee on Readiness, Committee on Armed Services, US Senate (Washington, D.C. (P.O. Box 37050, Washington, D.C. 20013): US Government Printing Office, 1998), 3-4; Brown, “Americans Favor Allowing Women.” A public opinion poll cited by Brown indicated 55 percent of Americans supported WIC roles while 42 percent did not.

${ }^{39}$ US Senate and General Accounting Office, Gender Issues Information on DOD's Assignment Policy and Direct Ground Combat Definition, 6. Emphasis added.

${ }^{40}$ Ibid., 2.

${ }^{41}$ The only restriction remaining to women's service in combat was a DOD policy. This is significant because, historically, Congress wanted to have oversight over women's service. The fact that Congress repealed all of the laws suggests Congress was both increasingly in favor of expanding women's roles and willing to allow the DOD to manage women's roles.

42 Phillip Carter, "War Dames,” The Washington Monthly, December 2002, under Violent Femmes. Carter indicates while there ought to be no doubt that the 1990s was a decade of progress for women serving in combat roles, the issue of WIC experienced relatively little attention during that period because there were no major, 
operations in non-linear combat environments with no clearly defined forward line of operations or rear safe zone. ${ }^{43}$ As a result, women became increasingly exposed to ground combat conditions regardless of assigned duty. Private Jessica Lynch's experience in 2003 is a compelling reflection of this circumstance. ${ }^{44}$ When the media queried Secretary of Defense Donald Rumsfeld's office on whether the DOD intended to change policy in light of women's increasing combat exposure, the DOD's spokeswoman responded, "The lines of combat have blurred over the years...the troops that were ambushed [Lynch]...weren't engaging in combat." She expanded the current policy's rationale by stating, "It has proven to not only provide the best opportunities for women to serve...but also provides the services with valuable personnel assets to meet their requirements." ${ }^{45}$

By 2004, 24 women had died in combat conditions, and the long-standing and heated debate over WIC was briefly quiet. ${ }^{46}$ Lory Manning, director of the Women in the Military Project at the Women's Research and Education Institute and a retired 25-year veteran of the

extended military ground engagements until operations began in Afghanistan and Iraq in the early 2000s. Hence this study "fast-forwards" from 1993 to 2001 in reviewing the elite's attitudes.

${ }^{43}$ Office of the Under Secretary of Defense (Personnel and Readiness), Report to Congress on the Review of Laws, Policies and Regulations Restricting the Service of Female Members in the US Armed Forces (Washington, DC: Dept. of Defense, 2012), 3.

${ }^{44}$ Jack Thomas, "From Private to Public Former POW Jessica Lynch Must Now Gear up for a Blitz from the Media," Boston Globe, April 5, 2003, sec. Living. Lynch was a supply clerk in a maintenance company driving a truck in a convoy in Iraq; she took a wrong turn and was ambushed by Iraqi forces. After suffering 11 days in captivity, beatings in her bed and numerous broken bones, Private Lynch was rescued by Special Operations Forces. Her story received extensive national media attention and even resulted in initial calls for an award of the Medal of Honor.

${ }^{45}$ David Freddoso, "Rumsfeld Retains Aspin's Rules," Human Events, May 19, 2003. It appears there is a logical disconnect in these two quotes from the same spokeswoman at the same event. It reflects the tension between observing social values and achieving military effectiveness. It appears as if the Army was willing to overlook the intent of DOD policy (to prevent women from experiencing combat conditions) to continue to place women where they needed them for effectiveness sake.

${ }^{46}$ Monica Davey and Tom Torok, "For 1,000 Troops, There Is No Going Home," New York Times, Late Edition (East Coast), September 9, 2004, sec. A. 
Navy, stated of the quiet, "What it means is that our view of women has changed... So people see this as less horrible. The horror of death is equal now." ${ }^{47}$

The Army's force posture also increasingly exposed women to ground combat conditions. Due to manning and retention challenges, the Army altered its internal policy to allow women to be assigned to Forward Supply Companies (FSC), which are non-combat units attached to units with a direct ground combat mission. The Army appears to have skirted the DOD policy, using creative wording and conditions to rationalize the change. The Secretary of the Army and the military elite denied any violation of policy ${ }^{48}$ When President Bush was queried about the Army's change, he deferred to military commanders' judgment stating, "There's no change of policy as far as I'm concerned. No women in combat." ${ }^{49}$ The circumstances indicate the Army consciously made a decision that increased women's exposure to ground combat conditions because military effectiveness was at stake. The Army needed qualified soldiers closer to the front lines, and women fulfilled this requirement. The Army conceded in internal debate, “"Army manpower cannot support elimination of female soldiers from all units designated to be units of action elements,' and all-male FSCs are impossible because recruiting numbers are too small.",50 If the military was resisting further inclusion of women based on relatively conservative social values, the Army's decision on FSCs suggests this belief was held in tension with an opposing force of military necessity. The military elite's willingness to increase women's role echoes Dempsey's assertion that there is not a great chasm

\footnotetext{
${ }^{47}$ Ibid.

48 “Army Revised Rules for Women," The Washington Times, March 14, 2005, http://www.washingtontimes.com/news/2005/mar/14/20050314-122924-8066r/.

49 "Despite Pressure, Bush Vows 'No Women in Combat,"” The Washington Times, January 11, 2005, http://www.washingtontimes.com/news/2005/jan/11/20050111-101005-5277r/.

${ }^{50}$ J. Michael Brower, "PRO: Expanding Roles for Women Warriors," The Officer 81, no. 2 (March 2005): third paragraph.
} 
between the military and civilian elite; the military does not have a military mindset that is dramatically out-of-step with society. As Huntington argued, the elite will favor effectiveness when national security is at stake. Ironically, this is true in spite of the military elite's comparatively conservative social values.

Congress noted the changing conditions of warfare and Army policy. In 2005, HASC Chairman Duncan Hunter (R-CA) and HASC Personnel Subcommittee Chairman John McHugh (R-NY) brought a measure before the HASC as an amendment to the 2006 NDAA that would force the Army to meet the intent of the 1993 DOD Direct Ground Combat Definition and Assignment Rule by prohibiting women's assignment to FSCs. ${ }^{51}$ Hunter stated, "Presently, the Army is unilaterally assigning servicewomen in land combat units. The committee's intent simply is to codify current [DOD] regulations." ${ }^{52}$ McHugh amplified Hunter's concern with, "Many Americans feel that [WIC] or combat support positions is not a bridge we want to cross at this point." ${ }^{53}$ The Hunter-McHugh measure narrowly passed in committee with the vote split along party lines. ${ }^{54}$ Twenty-seven HASC Democrats urged Hunter to strike the measure arguing it would tie the hands of commanders currently engaged in war and would undercut recruiting and retention of women..$^{55}$ A week later, Senator Hillary Clinton (D-NY) introduced a bill to

\footnotetext{
${ }^{51}$ Ann Scott Tyson, "More Objections to Women-in-Combat Ban," The Washington Post, May 18, 2005, sec. Politics, http://www.washingtonpost.com/wp-dyn/content/article/2005/05/17/AR2005051701356.html; Skaine, Women in Combat a Reference Handbook, 16.

${ }^{52}$ Tyson, "More Objections to Women-in-Combat Ban."

53 “No Women In Combat Passes House," Associated Press, May 19, 2005, http://www.military.com/NewsContent/0,13319,FL_women_051905,00.html.

${ }^{54}$ National Public Radio, “Analysis: Women in Combat," Talk of the Nation, May 19, 2005, http://search.proquest.com.aufric.idm.oclc.org/docview/190785519/A8E70C79E6A94DE9PQ/43?accountid=4332.

${ }^{55}$ Tyson, "More Objections to Women-in-Combat Ban."
} 
uphold the current policy and allow women to continue to serve in the roles prescribed by the Army. ${ }^{56}$

Rumsfeld responded by indicating the Army was working with Congress and battlefield commanders "to find an appropriate way that's consistent with our country's view on that subject." 57 The Army leadership responded, "The proposed amendment will cause confusion... and will send the wrong signal to the brave men and women fighting the global war on terrorism. This is not the time to create such confusion." 58 The Army also released a statement describing how its use of women in FSCs complied with DOD policy, illustrating the important contributions women were making to the wars. ${ }^{59}$ Lt Gen James Campbell, Army Director of Staff, indicated the Hunter-McHugh proposal would eliminate 21,925 jobs currently open to women. ${ }^{60}$ Association of the US Army President Gen Gordon Sullivan (Army retired) wrote to Hunter and ranking minority member Ike Skelton (D-MO), saying, "This is the wrong time to attempt to codify the role of [WIC]. With our troops engaged in the global war on terrorism, this proposed prohibition would be confusing and perplexing. To impose this restriction on commanders as they prepare for deployment would be detrimental to their units that have trained and readied together." Based on the overwhelming response from DOD and Army leaders, "members of Congress from both sides of the aisle let it be known that the provision would not have enough votes to pass." 61

\footnotetext{
56 "Sen. Clinton Introduces Bill to Uphold Role of Women in Combat," US Fed News Service, May 26, 2005, http://search.proquest.com.aufric.idm.oclc.org/docview/469708482/A8E70C79E6A94DE9PQ/45?accountid=4332.

57 "No Women In Combat Passes House."

58 “House Passes Defense Authorization Bill," Army 55, no. 7 (July 2005): 10.

${ }^{59}$ US Federal News Service, “Army Releases Statement on Proposed Legislation,” US Federal News Service, May 19, 2005, http://search.proquest.com.aufric.idm.oclc.org/docview/468672997/D5E7637131CB4A9APQ/58?accountid=4332.

${ }^{60}$ Tyson, "More Objections to Women-in-Combat Ban."

61 "House Passes Defense Authorization Bill."
} 
Regardless of the cause, merit and intensity of the debate on codifying the DOD's ground combat exclusion in the 2006 NDAA, the civilian and military elite harmonized their attitudes in favor of allowing the Army to continue to use women in FSCs because national security was at stake; the elite acknowledged the tension between military effectiveness and social values. The relative absence of significant opposition from the American public reflected its tacit support and enabled the civilian elite to yield to the military elite's position without notable political consequences. At that time, 66 percent of Americans favored women's role in combat. ${ }^{62}$

After the failure of the Hunter-McHugh amendment, debate about WIC was less intense and favored acknowledgement of the contributions, sacrifice, and success women delivered on the battlefield. The aforementioned statements of Clinton and Army leadership begin to illustrate this circumstance. In 2009, Representative Loretta Sanchez (D-CA) introduced a resolution honoring the exceptional service of WIC, citing in detail the contributions and sacrifices of women to include 120 who died, 66 in combat. ${ }^{63}$ Later that year, McHugh stated in his confirmation hearing for Secretary of the Army he now supported keeping WIC, citing the 1993 Aspin policy as effective. ${ }^{64}$ Collectively, statements like these began to illustrate that the civilian and military elite increasingly supported WIC because women's service favored both military effectiveness and society's values. From 2007 on, polls consistently illustrated approximately 74 percent of Americans supported WIC. ${ }^{65}$

\footnotetext{
${ }^{62}$ Brown, "Americans Favor Allowing Women."

63 "Rep. Sanchez Introduces Resolution Honoring Women in Combat," US Fed News Service, Including US State News, November 17, 2009, http://search.proquest.com.aufric.idm.oclc.org/docview/470402227/A8E70C79E6A94DE9PQ/85?accountid=4332.

${ }^{64}$ Skaine, Women in Combat a Reference Handbook, 18.

${ }^{65}$ Brown, "Americans Favor Allowing Women."
} 
The first major effort in the late-war period supporting greater inclusion of women was the 2011 Military Leadership Diversity Commission (MDLC), created by the 2009 NDAA. ${ }^{66}$ The MDLC's purpose was to "conduct a comprehensive evaluation and assessment of policies and practices that shape diversity among military leaders." ${ }^{67}$ One of the three guiding, interrelated goals of all of the MDLC's recommendations was to "maximize mission effectiveness." ${ }^{68}$ The MDLC was comprised of 23 civil-military elite-six civilians and 17 active and retired military. ${ }^{69}$

There are three themes in the MDLC's findings that are applicable to the evolution of the elite's perspectives on WIC. First, the MDLC found that DOD efforts to increase diversity were limited by the DOD's inattention to changing its culture. Lt Gen Julius Becton illustrated this limitation in his remarks to the MDLC: "We have one 4-star female, there is no doubt in my mind that she could have commanded a combat division. So, the culture said no, simple as that."70 The MDLC found that "deep changes...cannot be instituted with a push of a button" and "thousands of decision-makers in similar situations [must] go beyond the comfort and familiarity of old ways of thinking."71 The MDLC indicated diversity and social change is best implemented by “" unfreezing' old attitudes and behaviors, implemented through forward

\footnotetext{
${ }^{66}$ US Congress, H.R. 5658 (110th): Duncan Hunter National Defense Authorization Act for Fiscal Year 2009, 2008, Sec 595, https://www.govtrack.us/congress/bills/110/hr5658/text.

${ }^{67}$ United States and Military Leadership Diversity Commission, From Representation to Inclusion Diversity Leadership for the 21st-Century Military: Final Report ([Arlington, VA]: Military Leadership Diversity Commission, 2011), cover letter.

${ }^{68}$ Ibid., 8.

${ }^{69}$ US Congress, Text of H.R. 5658 (110th), Sec 595. Note: A number of the military elite were command chiefs, which are not normally considered part of the military elite. However, it is evident that they were chosen for their institutional perspective. Therefore it is reasonable to consider them part of the elite for this purpose.

${ }^{70}$ United States and Military Leadership Diversity Commission, From Representation to Inclusion Diversity Leadership for the 21st-Century Military, 67.

${ }^{71}$ Ibid., 25.
} 
movement, and then sustained by 'refreezing' new behaviors and attitudes."72 Warfare serves as a vehicle for social and cultural change, but the wars in Afghanistan and Iraq, in particular, aided women's inclusion in combat roles through this unfreeze-refreeze process. Second, the MDLC echoed, "combat exclusion policies do not reflect the current operational environment."73 Third, and most important, the MDLC found the argument that WIC would reduce unit cohesion and military effectiveness had little evidence to support it. Indeed, "a majority of focus group participants felt that women serving in combat in Iraq and Afghanistan have had a positive effect on mission accomplishment." ${ }^{74}$ The MDLC indicated the combat exclusion policies prevented commanders from picking the most capable members. Overall, the MDLC decided by a majority vote to recommend all combat exclusion policies be rescinded using a phased approach. ${ }^{75}$

A Washington Post poll conducted in 2011 after the MDLC released its report found 73 percent of the American public, 80 percent of Democrats and 62 percent of Republicans supported giving women direct combat roles. ${ }^{76}$ A month later Secretary of Defense Robert Gates said of the ground combat exclusion: "So, you know, there's a certain contradiction there and frankly the policy hasn't caught up to the reality in some respects. I am confident that this is an area that is going to change. Time scale of the change, I have no idea. But I think the first place it has to start is with the reality that in a lot of places we're already there."77 Gates knew

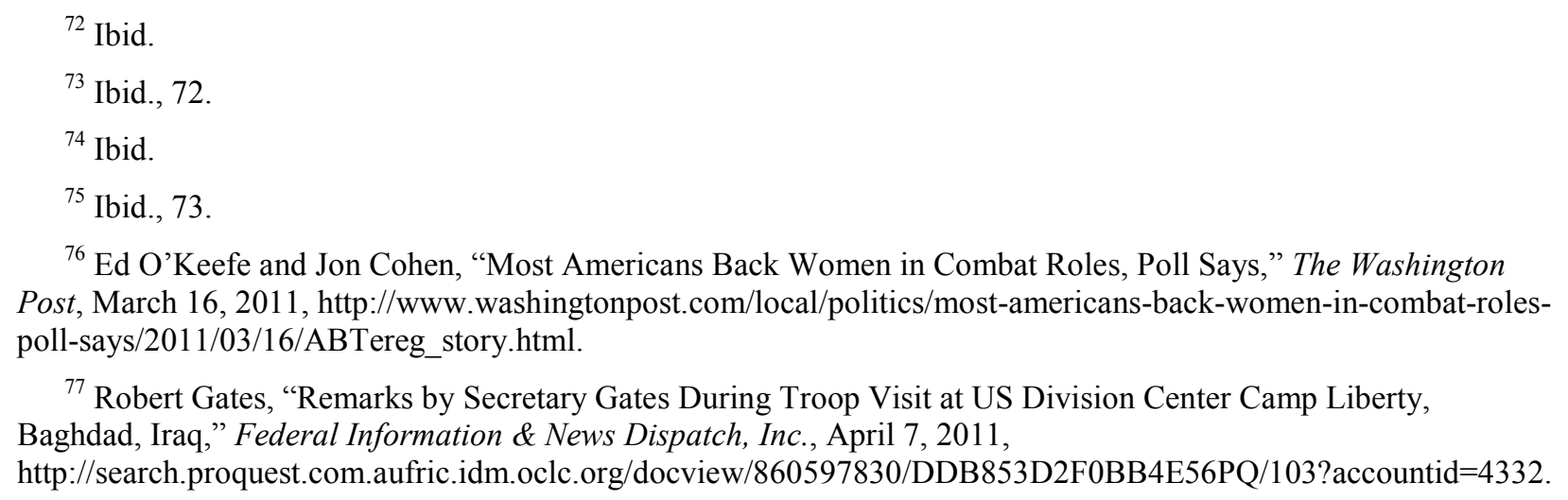

${ }^{77}$ Robert Gates, "Remarks by Secretary Gates During Troop Visit at US Division Center Camp Liberty, Baghdad, Iraq," Federal Information \& News Dispatch, Inc., April 7, 2011, http://search.proquest.com.aufric.idm.oclc.org/docview/860597830/DDB853D2F0BB4E56PQ/103?accountid=4332. 
Congress deferred to military judgment regarding the policy on WIC. So why did he state the change is coming but he was not sure when? A likely conclusion is he knew the military elite were at or near a tipping point of support. It also reflects the need to achieve sufficient harmony among Congress, the military elite, and the public — each possessing unique interests; he was likely waiting for clear indications of harmony to change the policy. These circumstances suggest the experience of war in Afghanistan and Iraq was a social change agent, illustrating to the elite that women serving in ground combat roles would have support of the public and a positive effect on military effectiveness.

Another significant event of the late-war period which paved the way ahead for greater inclusion of women was the DOD's 2012 Report to Congress on the Review of Laws, Policies and Regulations Restricting the Service of Female Members in the US Armed Forces. The report was completed in response to a requirement in the 2011 NDAA for the DOD to assess all remaining gender-restricting policies. ${ }^{78}$ Like the MLDC, the DOD found the combat environment had changed and women should no longer be excluded from collocating with combat units. The DOD further concluded women could also be assigned below the brigade, but not below the battalion level, and changed the policy, citing the decision was "based on 10 years of recent combat experiences." ${ }^{\text {79 }}$ The DOD stated that expanding opportunities would allow the Department to "assess the suitability and relevance of the direct ground combat unit assignment prohibition and inform future policy decisions." ${ }^{80}$ The report's tone, which reflects attitudes of the military elite and Secretary of Defense Leon Panetta, shows acknowledgement of the capabilities and contributions of women to military effectiveness based on recent combat

\footnotetext{
${ }^{78}$ Office of the Under Secretary of Defense (Personnel and Readiness), Report to Congress on the Review of Laws, Policies and Regulations Restricting the Service of Female Members in the US Armed Forces, i.

${ }^{79}$ Ibid., 3.

${ }^{80}$ Ibid., 14.
} 
operations. Indeed, the report is essentially void of the "standard" historical arguments against women's service. In unveiling the report and articulating policy changes, DOD Press Secretary George Little stated, "Secretary Panetta strongly supports these changes. He recognizes that over the last decade of war, women have contributed in unprecedented ways to the military's mission.... They have proven their ability to serve in an expanding number of roles on and off the battlefield." ${ }^{81}$ Deputy Undersecretary of Defense for Military Personnel Policy Virginia Penrod stated, "This is the beginning of the end" of the combat exclusion policy. ${ }^{82}$ Maj Gen Gary Patton, Principal Director for DOD Military Personnel Policy stated, "I've seen women perform in an expanded role. I'm very proud of them." ${ }^{83}$

Although ideological and interest divides persisted, the attitudes of the elite were changing and harmonizing. Within days of the DOD report's release, Senator Scott Brown (RMA), a Senate Armed Services Committee (SASC) member and a lieutenant colonel in the Massachusetts National Guard, broke from leaders of the Republican Party by urging Panetta to allow women to serve in ground combat; "We have an obligation to expand the professional opportunities available to women, especially considering their sacrifices [in Afghanistan and Iraq]. Doing so, in my view, would improve military effectiveness, not detract from it." 84 Brown joined "a growing chorus of lawmakers, most of them Democrats, who want[ed] Panetta to expand the combat roles of women without delay." 85

81 "DOD News Briefing on Women in Service Review" (Federal Information \& News Dispatch, Inc., February 9, 2012), http://search.proquest.com.aufric.idm.oclc.org/docview/920847997/DDB853D2F0BB4E56PQ/119?accountid=4332.

82 “Army to Open Six MOSs to Women," Targeted News Service, February 9, 2012, http://search.proquest.com.aufric.idm.oclc.org/docview/920683688/DDB853D2F0BB4E56PQ/117?accountid=4332.

83 Ibid.

${ }^{84}$ Bryan Bender, "Brown Supports Women in Combat: US Senator Asks Greater Opportunities for Female Troops," Boston Globe, February 23, 2012, B.1.

${ }^{85}$ Ibid. 
The policy excluding women from ground combat roles was rescinded in January 2013. Chairman of the Joint Chiefs of Staff Gen Martin Dempsey issued a memo to Panetta stating, "The time has come to rescind the direct [ground] combat exclusion rule for women and to eliminate all unnecessary gender-based barriers to service. The Joint Chiefs of Staff unanimously join me in proposing that we move forward with the full intent to integrate women into occupational fields to the maximum extent possible...We recognize the bravery and contributions of women." ${ }^{\prime 86}$ Dempsey indicated two of the key driving principles were "preserving unit readiness, cohesion, and morale" and "retaining the trust and confidence of the American people to defend this nation by promoting policies that maintain the best quality and most qualified people." ${ }^{87}$ Two weeks later, Panetta and Dempsey issued a joint memo stating, "Thousands of women have served alongside men in Iraq and Afghanistan, and like men, have been exposed to hostile enemy action in those countries." ${ }^{88}$

In the discussion following the release of the memoranda and Panetta's public statement, it became evident the military initiated the policy shift unilaterally with little or no outside influence. ${ }^{89}$ The White House staff was surprised by the decision, having not reviewed the changes in advance. ${ }^{90}$ Chris Jacob, the policy director of the Service Women's Action Network stated, "It's significant that the change came from the uniformed side, rather than being forced

\footnotetext{
${ }^{86}$ Gen Martin E. Dempsey, "Women in the Service Implementation Plan" (Department of Defense, 2013), http://www.defense.gov/news/WISRImplementationPlanMemo.pdf.

${ }^{87}$ Ibid.

${ }^{88}$ Leon E. Panetta and Gen Martin E. Dempsey, "Elimination of the 1994 Direct Ground Combat Definition and Assignment Rule" (Department of Defense, January 24, 2013), http://www.defense.gov/news/WISRJointMemo.pdf.

${ }^{89}$ Leon E. Panetta, "Statement on Women in Service" (Pentagon, January 24, 2013), http://www.defense.gov/speeches/speech.aspx?speechid=1746; Elisabeth Bumiller and Thom Shanker, "Pentagon Is Set to Lift Combat Ban for Women," New York Times, January 24, 2013, http://www.nytimes.com/2013/01/24/us/pentagon-says-it-is-lifting-ban-on-women-incombat.html?pagewanted $=$ all\&_r $=0$.

${ }^{90}$ Bumiller and Shanker, "Pentagon Is Set to Lift Combat Ban for Women."
} 
on the uniformed side by the civilian leadership."91 The New York Times reported, "Although in the past some Republican members of the House have balked at allowing [WIC], on Wednesday there appeared to be bipartisan endorsement for the decision." 92 A Gallup poll conducted immediately after the DOD rescinded the policy found 74 percent of the American public, 83 percent of Democrats and 70 percent of Republicans supported women in direct combat roles. ${ }^{93}$

Support of the new policy was founded on recognition of women's service in Afghanistan and Iraq. Senator Kelly Ayotte (R-NH), stated she was pleased by the decision and said it "reflects the increasing role that female service members play in securing our country.",94 Senator Richard Blumenthal (D-CT) stated, "This historic step reflects the real life lessons learned in Iraq and Afghanistan - that women have served heroically and effectively in combat, and America can be proud of their courage and skill." ${ }^{95}$ During the Congressional Women in Service Review that followed in July 2013, the attitudes of the elite became clearer.

Representative Joe Wilson (R-SC), Chairman of the House Subcommittee on Military Personnel, stated, "Over the last decade women have served exceptionally in many positions in combat." 96 Representative Susan Davis (D-CA), Ranking Member of the House Subcommittee on Military Personnel, stated, "I am very pleased that the Secretary rescinded the policy. Women have served with distinction, including under combat conditions in today's All-Volunteer Force, and

${ }^{91}$ Ibid.

${ }^{92}$ Ibid.

${ }^{93}$ Brown, "Americans Favor Allowing Women."

${ }^{94}$ Bumiller and Shanker, "Pentagon Is Set to Lift Combat Ban for Women."

95 "Senator Blumenthal Applauds Decision To Lift Ban On Women In Combat," Federal Information \& News Dispatch, Inc., January 23, 2013, http://search.proquest.com.aufric.idm.oclc.org/docview/1272342081/DDB853D2F0BB4E56PQ/147?accountid=433 2 .

${ }^{96}$ US House of Representatives, Committee on Armed Services, and Subcommittee on Military Personnel, Women in Service Reviews: Hearing Before the Subcommittee on Military Personnel of the Committee on Armed Services, House of Representatives, One Hundred Thirteenth Congress, First Session, Hearing Held July 24, 2013. (US Government Printing Office, 2013), 29, http://purl fdlp.gov/GPO/gpo40895. 
the conflicts in Iraq and Afghanistan have proven that future conflicts put all those who serve on the battlefield under the same threat."97 Lt Gen Robert Milstead, Marine Deputy Commandant for Manpower, stated, "The...Marine Corps are dedicated to maintaining the highest levels of combat readiness... The talent pool from which we select our finest warfighters will consist of all qualified individuals, regardless of gender." 98 Lt Gen Howard Bromberg, Army Deputy Chief of Staff for Personnel, stated, "Our goal is to integrate women leaders and soldiers...as expeditiously as possible. We will not sacrifice warfighting capability, the trust of Congress, or that of the American people as we seek to enhance force readiness and capability." "99 Senior military officers representing the Navy, Air Force, US Special Operations Command, and the DOD also testified with similar statements of support. However, it is evident in the statements of the military elite that the closer to direct ground combat that service member's function is, the more nuanced their statement was with language highlighting the necessity to continue to focus on military effectiveness. For example, Lt Gen Milstead stated, “Opening all...positions across the Marine Corps immediately could have harmful unintended consequences. We must carefully review the requirements for each...position." ${ }^{100}$ Lt Gen Milstead's attitude suggests that in spite of increased harmony with the civilian elite, the military elite will continue to be mindful of their primary interest, military effectiveness. Similarly, the civilian elite will likely continue to be mindful of societal values. The good news is both the civilian and military elite were willing to engage in dialogue that served the interests of both the military and civil society.

\footnotetext{
${ }^{97}$ Ibid., 2.

${ }^{98}$ Ibid., 48.

${ }^{99}$ Ibid., 4.

${ }^{100}$ Ibid., 46.
} 


\section{Conclusion}

A fundamental concern in the debate about a civil-military gap is that the space between the values or attitudes of civilian society and the military may become so wide it threatens civilmilitary cooperation and military effectiveness. This study sheds light on that concern by examining the elite's attitudes on WIC, a social issue at the heart of the gap, as the nation regrouped after the Gulf War then fought in Afghanistan and Iraq. It revealed that the military elite, who have historically limited women's roles due to concerns over a negative impact on military effectiveness, expanded women's roles primarily to increase military effectiveness but also to mirror society's values. It revealed that civilians facilitated and monitored the expansion of women's roles primarily to synchronize with society's values, while simultaneously respecting military concerns for effectiveness. Ultimately, the expansion of women's roles served as a proving ground, illustrating to the civilian and military elite that women's service had both society's acceptance and a positive impact on effectiveness, thereby harmonizing elite attitudes.

Although debate of the issue was significant, it is evident the civilian and military elite engaged in frank dialogue on mutual interests to constructively reconcile their differences over time and agreed to favor military effectiveness over social values because national security was at stake. With social values residing at the heart of the civil-military gap, this study suggests that the civil-military gap is neither a chasm nor unbridgeable. The nature of the relations of the civilian and military elite suggests there is no immediate cause for concern. 


\section{Appendix}

Table 1. ${ }^{101}$

RETIRED FLAG OFFICER SURVEY

COMBAT ASSIGNMENT RESPONSE RATES BY SERVICE *

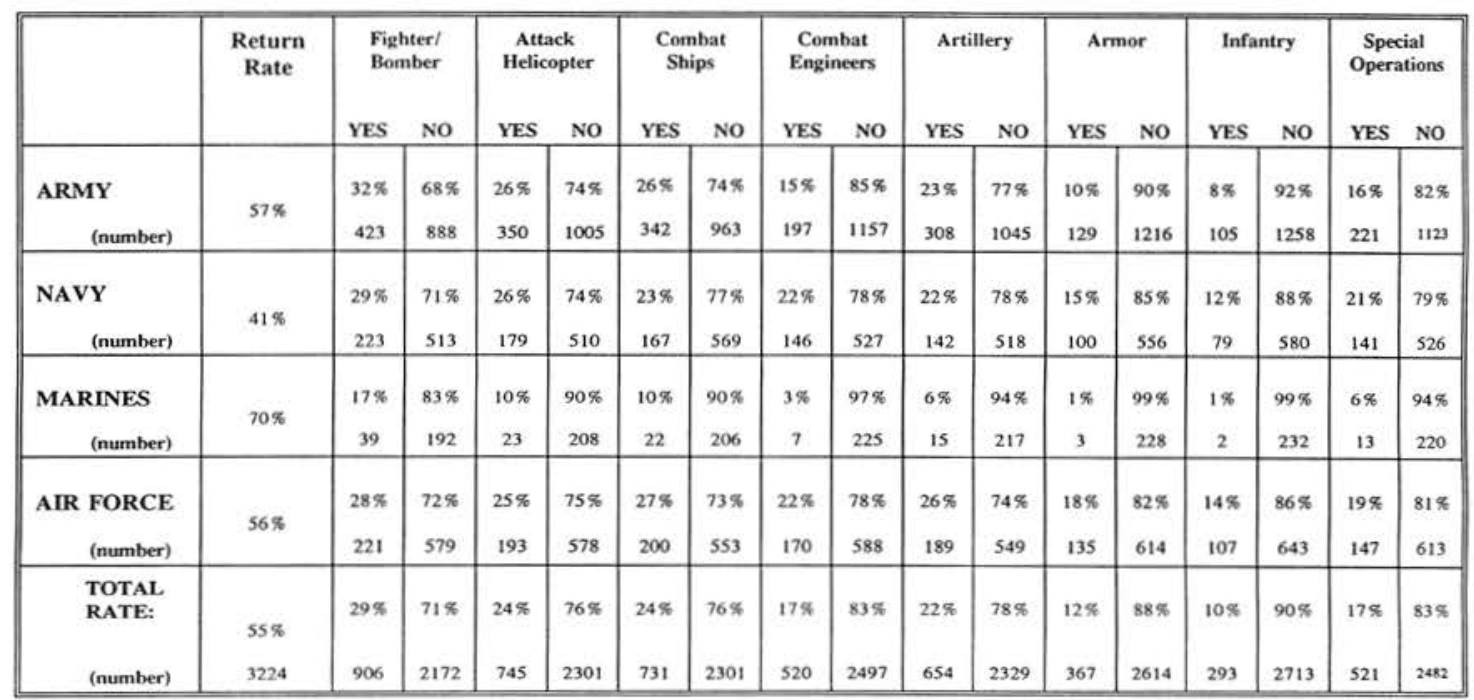

* Response rates indicate the proportion of actual flag officers responses.

$\mathrm{Tab}$

RETIRED FLAG OFFICER SURVEY COMBAT ASSIGNMENT RESPONSE RATE BY RETIREMENT YEAR GROUP

le 2 .

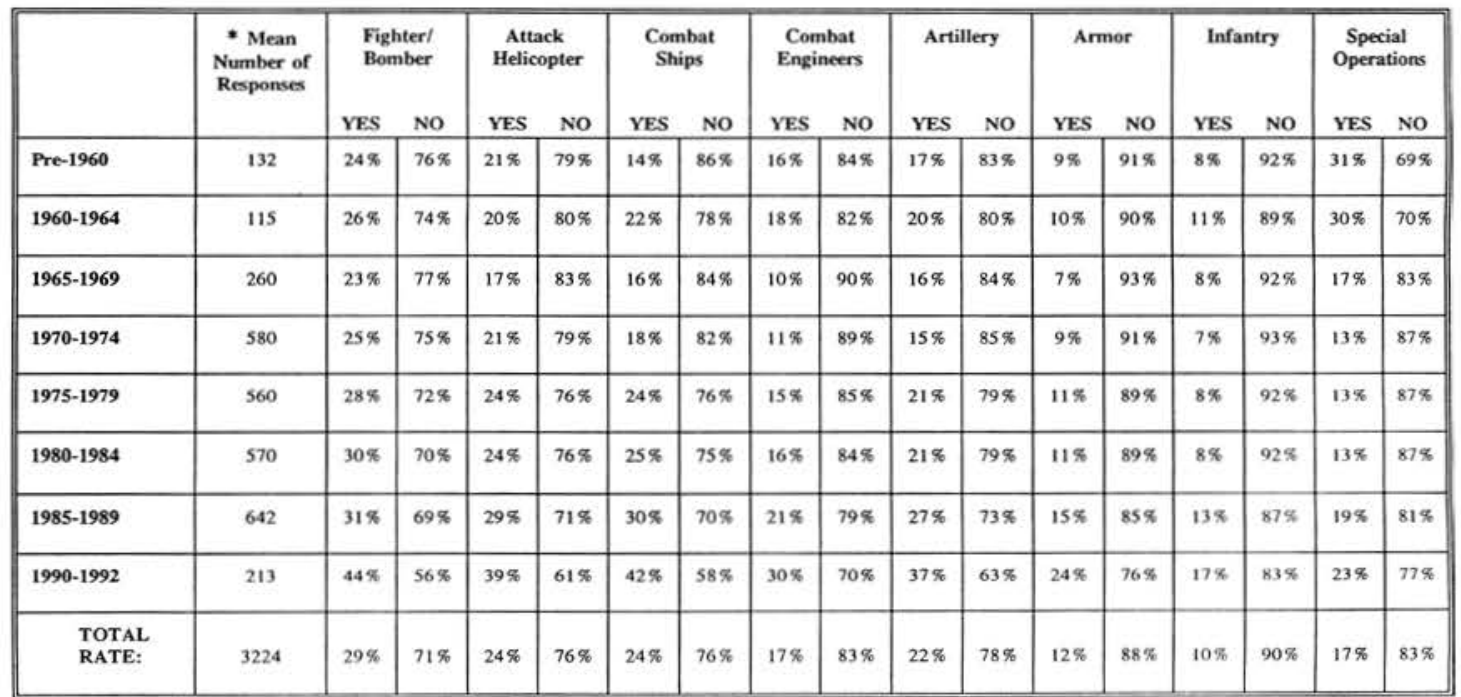

- Some officers did not indicate answers to all eight specialties. Percentages represent the proportion of YES/NO of those who answered.

${ }^{101}$ United States. Presidential Commission on the Assignment of Women in the Armed Forces, Report to the President, D-8 and D-9. Tables 1 and 2 above are shown are found on these pages, respectively. 


\section{Bibliography}

Applebaum, Anne. "When Women Go to War." The Washington Post, March 26, 2003, A.17.

Armor, David J. "Women in Combat: Rationale and Implications." E-International Relations, March 8, 2013. http://www.e-ir.info/2013/03/08/women-in-combat-rationale-and-implications/.

“Army Revised Rules for Women.” The Washington Times, March 14, 2005. http://www.washingtontimes.com/news/2005/mar/14/20050314-122924-8066r/.

“Army to Open Six MOSs to Women." Targeted News Service. February 9, 2012. http://search.proquest.com.aufric.idm.oclc.org/docview/920683688/DDB853D2F0BB4E56PQ/117?account $\mathrm{id}=4332$.

Aspin, Les. "Direct Ground Combat Definition and Assignment Rule." Department of Defense, January 13, 1994. http://big.assets.huffingtonpost.com/irectGroundCombatDefinitionAndAssignmentRule.pdf.

Babbin, Jed. "The Men Who Would Be CINC.” The American Spectator, February 2003.

Bailey, Beth L. America's Army: Making the All-Volunteer Force. Cambridge, MA: Harvard University Press, 2009. http://site.ebrary.com/id/10402486.

Baker, Henderson. "Women in Combat: A Culture Issue.” US Army War College, 2006. http://www.dtic mil/docs/citations/ADA449305.

Barry, Ben. "Women in Combat." Survival 55, no. 2 (April 3, 2013): 19-30. doi:10.1080/00396338.2013.784461.

Bender, Bryan. "Army Secretary Rejects Change in Policy on Women in Combat." Boston Globe, January 29, 2005, A.11.

_ . "Brown Supports Women in Combat: US Senator Asks Greater Opportunities for Female Troops." Boston Globe, February 23, 2012, B.1.

Bicksler, Barbara A., Curtis L. Gilroy, John T. Warner, and Donald Rumsfeld. The All-Volunteer Force: Thirty Years of Service. Washington, D.C.: Brassey's Inc., 2004.

"Broad Support for Combat Roles for Women." Pew Research Center for the People and the Press, January 29, 2013. http://www.people-press.org/2013/01/29/broad-support-for-combat-roles-for-women/.

Brower, J. Michael. "PRO: Expanding Roles for Women Warriors.” The Officer 81, no. 2 (March 2005): $38,42-45$.

Brown, Alyssa. “Americans Favor Allowing Women.” Gallop, January 25, 2013. http://www.gallup.com/poll/160124/americans-favor-allowing-women-combat.aspx.

Bumiller, Elisabeth, and Thom Shanker. "Pentagon Is Set to Lift Combat Ban for Women." New York Times, January 24, 2013. http://www.nytimes.com/2013/01/24/us/pentagon-says-it-is-lifting-ban-on-women-incombat.html?pagewanted=all\&_r $=0$.

Burrelli, David F. Women in Combat: Issues for Congress. Congressional Research Service, May 9, 2013.

Calmes, Jackie. "GOP Candidates Joust in Iowa On Topics From China to Ethanol." Wall Street Journal, Eastern Edition. December 14, 1999.

Carter, Phillip. "War Dames.” The Washington Monthly, December 2002.

Cohen, Janet Langhart, and Armed Forces Television Network. "Interview with President Bill Clinton." Weekly Compilation of Presidential Documents 35, no. 9 (March 8, 1999): 353.

Cohen, William S. "Remarks as Delivered by Secretary of Defense William S. Cohen." Speech, Yale University, September 26, 1997. http://www.defense.gov/Releases/Release.aspx?ReleaseID=1459.

Daniel, Lisa. "Panel Says Rescind Policy on Women in Combat." American Forces Press Service, DoD, March 7, 2001. http://www.defense.gov/news/newsarticle.aspx?id=63057. 
Davey, Monica, and Tom Torok. "For 1,000 Troops, There Is No Going Home." New York Times, Late Edition (East Coast). September 9, 2004, sec. A.

Dempsey, Gen Martin E. “Women in the Service Implementation Plan.” Department of Defense, 2013. http://www.defense.gov/news/WISRImplementationPlanMemo.pdf.

Dempsey, Jason K. Our Army: Soldiers, Politics, and American Civil-Military Relations. Princeton: Princeton University Press, 2010.

Department of Defense. Defense Advisory Committee on Women in the Services Annual Report, 2013. http://dacowits.defense.gov/Portals/48/Documents/Reports/2013/Annual\%20Report/2013_DACOWITS_R eport_FINAL.pdf.

"Despite Pressure, Bush Vows 'No Women in Combat." The Washington Times, January 11, 2005. http://www.washingtontimes.com/news/2005/jan/11/20050111-101005-5277r/.

"DOD News Briefing on Women in Service Review." Federal Information \& News Dispatch, Inc., February 9, 2012.

http://search.proquest.com.aufric.idm.oclc.org/docview/920847997/DDB853D2F0BB4E56PQ/119?account $\mathrm{id}=4332$.

Donnelly, Elaine. “Army Plays Games With Women-in-Combat Rule.” Human Events, April 4, 2005.

—_. "The Credibility Crisis." United States Naval Institute. Proceedings 126, no. 8 (August 2000): 42-48.

Feaver, Peter. Choosing Your Battles: American Civil-Military Relations and the Use of Force. Princeton: Princeton University Press, 2004.

Feaver, Peter D., Richard H. Kohn, and Lindsay P. Cohn. "The Gap Between Military and Civilian in the United States in Perspective." In Soldiers and Civilians: The Civil-Military Gap and American National Security. Cambridge, MA: MIT Press, 2001.

Feaver, Peter, and Richard H. Kohn. Soldiers and Civilians : The Civil-Military Gap and American National Security. Cambridge, MA: MIT Press, 2001.

Freddoso, David. “Rumsfeld Retains Aspin's Rules.” Human Events, May 19, 2003.

Gates, Robert. "Remarks by Secretary Gates During Troop Visit at U.S. Division Center Camp Liberty, Baghdad, Iraq." Federal Information \& News Dispatch, Inc., April 7, 2011. http://search.proquest.com.aufric.idm.oclc.org/docview/860597830/DDB853D2F0BB4E56PQ/103?account $\mathrm{id}=4332$.

Harrell, Margaret C, Laura L Miller, Department of Defense, and National Defense Research Institute (U.S.). New Opportunities for Military Women: Effects Upon Readiness, Cohesion, and Morale. Santa Monica, CA: Rand, 1997.

Harrell, Margaret C., United States, Department of Defense, and Office of the Secretary of Defense. Assessing the Assignment Policy for Army Women. Santa Monica, CA: RAND National Defense Research Institute, 2007. http://site.ebrary.com/id/10225513.

Hillen, John. "Must US Military Culture Reform?" Parameters 29, no. 3 (Autumn 1999): 9-23.

Holsti, Ole R. "Of Chasms and Convergences: Attitudes and Beliefs of Civilians and Military Elites at the Start of a New Millennium." Soldiers and Civilians: The Civil-Military Gap and American National Security, 2001, 15-100.

“House Passes Defense Authorization Bill.” Army 55, no. 7 (July 2005): 10.

Huntington, Samuel P. The Soldier and the State: The Theory and Politics of Civil-Military Relations. Cambridge: Belknap Press of Harvard University Press, 1957.

Janowitz, Morris. The Professional Soldier, a Social and Political Portrait. Glencoe, IL: Free Press, 1960.

Karsten, Peter. Soldiers and Society: The Effects of Military Service and War on American Life. Grass Roots Perspectives on American History ; No. 1. Westport, CT: Greenwood Press, 1978. 
Kier, Elizabeth. "Homosexuals in the U.S. Military: Open Integration and Combat Effectiveness." International Security 23, no. 2 (October 1, 1998): 5-39. doi:10.2307/2539378.

Kohn, Richard H. "The Social History of the American Soldier: A Review and Prospectus for Research." The American Historical Review 86, no. 3 (June 1, 1981): 553-67. doi:10.2307/1860370.

Lister, Sara E. “Gender and the Civil-Military Gap." United States Naval Institute. Proceedings 126, no. 1 (January 2000): 50-53.

MacKenzie, Megan H. "Let Women Fight: Ending the U.S. Military's Female Combat Ban.” Foreign Affairs 91 (2012): 32.

McSally, Martha. "US Military's Last Barrier to Equality: Ban on Women in Combat." The Christian Science Monitor. January 28, 2011, sec. Opinion.

McSally, Martha E. "Defending America in Mixed Company: Gender in the U.S. Armed Forces." Daedalus 140, no. 3 (Summer 2011): 148-64.

Miller, Laura L., and John Allen Williams. "Do Military Policies on Gender and Sexuality Undermine Combat Effectiveness?" In Soldiers and Civilians: The Civil-Military Gap and American National Security. Cambridge, MA: MIT Press, 2001.

Moskos, Charles C. "The Sociology of Combat.” Contemporary Sociology 13, no. 4 (July 1, 1984): 420-22. doi:10.2307/2069041.

National Public Radio. “Analysis: Debate Over Whether Women Should Be Allowed in Direct Combat Positions in the Military." Day to Day, May 19, 2005.

http://search.proquest.com.aufric.idm.oclc.org/docview/190778058/A8E70C79E6A94DE9PQ/42?accounti $\mathrm{d}=4332$.

_. "Analysis: Women in Combat." Talk of the Nation, May 19, 2005.

http://search.proquest.com.aufric.idm.oclc.org/docview/190785519/A8E70C79E6A94DE9PQ/43?accounti $\mathrm{d}=4332$.

_ . "Interview: Walter Jones, Loretta Sanchez and Turrie Peoples Discuss the House Subcommittee Amendment Barring Women from Serving in Forward Support Companies in the Military." Weekend All Things Considered, May 15, 2005.

http://search.proquest.com.aufric.idm.oclc.org/docview/190151132/D5E7637131CB4A9APQ/47?accounti $\mathrm{d}=4332$.

"No Women In Combat Passes House." Associated Press, May 19, 2005. http://www.military.com/NewsContent/0,13319,FL_women_051905,00.html.

Office of the Under Secretary of Defense (Personnel and Readiness). Report to Congress on the Review of Laws, Policies and Regulations Restricting the Service of Female Members in the U.S. Armed Forces. Washington, DC: Dept. of Defense, 2012.

O'Hanlon, Michael E. “The U.S. Should Take a Gradual Approach to Women in Combat.” The Brookings Institution. Accessed November 15, 2014. http://www.brookings.edu/research/opinions/2013/01/25women-combat-ohanlon.

O'Keefe, Ed, and Jon Cohen. "Most Americans Back Women in Combat Roles, Poll Says." The Washington Post, March 16, 2011. http://www.washingtonpost.com/local/politics/most-americans-back-women-incombat-roles-poll-says/2011/03/16/ABTereg_story html.

Panetta, Leon E. "Statement on Women in Service." Pentagon, January 24, 2013. http://www.defense.gov/speeches/speech.aspx?speechid=1746.

Panetta, Leon E., and Gen Martin E. Dempsey. "Elimination of the 1994 Direct Ground Combat Definition and Assignment Rule." Department of Defense, January 24, 2013. http://www.defense.gov/news/WISRJointMemo.pdf. 
Parham, Alice W. "Quiet Revolution: Repeal of the Exclusionary Statutes in Combat Aviation - What We Have Learned from a Decade of Integration." William \& Mary Journal of Women and the Law 12 (2006 2005): 377.

Parrish, Karen. "Hagel Addresses Iran, Pay, Women in Combat." American Forces Press Service, DoD, December 6, 2013. http://www.defense.gov/news/newsarticle.aspx?id=121288.

"New Policies Reflect Realities of Modern Warfare, Officials Say." American Forces Press Service, DoD, 2012. http://www.defense.gov/News/NewsArticle.aspx?ID=67131.

Preston, Kenneth O., Peter J. Schoomaker, and Francis J. Harvey. "A Message from the Army Leadership." Soldiers 60, no. 3 (March 2005): 3.

"Rep. Sanchez Introduces Resolution Honoring Women in Combat." US Fed News Service, Including US State News. November 17, 2009. http://search.proquest.com.aufric.idm.oclc.org/docview/470402227/A8E70C79E6A94DE9PQ/85?accounti $\mathrm{d}=4332$.

Ricks, Thomas E. "The Widening Gap Between Military and Society." The Atlantic, July 1997. http://www.theatlantic.com/magazine/archive/1997/07/the-widening-gap-between-military-andsociety $/ 306158 /$.

Rohall, David E., Morten G. Ender, and Michael D. Matthews. "The Effects of Military Affiliation, Gender, and Political Ideology on Attitudes toward the Wars in Afghanistan and Iraq." Armed Forces \& Society 33, no. 1 (October 1, 2006): 59-77. doi:10.1177/0095327X06289817.

Schmitt, Eric. "House Votes Military Budget, Cutting Arms Programs.” The New York Times, May 23, 1991, sec. U.S. http://www.nytimes.com/1991/05/23/us/house-votes-military-budget-cutting-arms-programs.html.

"Senator Blumenthal Applauds Decision To Lift Ban On Women In Combat." Federal Information \& News Dispatch, Inc., January 23, 2013. http://search.proquest.com.aufric.idm.oclc.org/docview/1272342081/DDB853D2F0BB4E56PQ/147?accou ntid $=4332$.

"Sen. Clinton Introduces Bill to Uphold Role of Women in Combat." US Fed News Service. May 26, 2005. http://search.proquest.com.aufric.idm.oclc.org/docview/469708482/A8E70C79E6A94DE9PQ/45?accounti $\mathrm{d}=4332$.

Skaine, Rosemarie. Women in Combat a Reference Handbook. Santa Barbara, CA: ABC-CLIO, 2011. http://ebooks.abc-clio.com/?isbn=9781598844603.

Solaro, Erin. “GI Janes Caught in Culture Wars Crossfire.” The Christian Science Monitor. June 1, 2005, sec. Opinion.

Stevenson, Richard W. "Bush's Talks May Vary, but Always a Reminder: Sept. 11.” New York Times. October 27, 2004, sec. National. http://search.proquest.com.aufric.idm.oclc.org/docview/92770242/abstract/6CAE65F88C3A48F6PQ/9?acc ountid $=4332$.

Stone, Andrea. "Panel's Decision Reheats Women-in-Combat Debate ; Pentagon to Review Issue That Some Say Renews Cultural Battle." USA TODAY. May 20, 2005, sec. News.

Thomas, Jack. "From Private to Public Former POW Jessica Lynch Must Now Gear up for a Blitz from the Media." Boston Globe. April 5, 2003, sec. Living.

Triangle Institute for Security Studies. The Civil-Military Gap in the United States: Does It Exist, Why, and Does It Matter?. Edited by Thomas S. Szayna. Santa Monica, CA: RAND Corp, 2007.

Tyson, Ann Scott. "More Objections to Women-in-Combat Ban." The Washington Post, May 18, 2005, sec. Politics. http://www.washingtonpost.com/wp-dyn/content/article/2005/05/17/AR2005051701356.html.

United States, and Military Leadership Diversity Commission. From Representation to Inclusion Diversity Leadership for the 21st-Century Military: Final Report. [Arlington, VA]: Military Leadership Diversity Commission, 2011. 
United States. Presidential Commission on the Assignment of Women in the Armed Forces. Report to the President: November 15, 1992: The Presidential Commission on the Assignment of Women in the Armed Forces. Washington, DC: The Commission, 1992.

US Congress. H.R.2100 - National Defense Authorization Act for Fiscal Years 1992 and 1993, 1991. http://thomas.loc.gov/cgi-bin/bdquery/D?d102:2:/temp/ bdcFzl:@@@L\&umm2=m\&.

- H.R. 5658 (110th): Duncan Hunter National Defense Authorization Act for Fiscal Year 2009, 2008. https://www.govtrack.us/congress/bills/110/hr5658/text.

-. National Defense Authorization Act for Fiscal Years 1992 and 1993 (1991 - H.R. 2100), 1991. https://www.govtrack.us/congress/bills/102/hr2100.

US Federal News Service. “Army Releases Statement on Proposed Legislation.” US Federal News Service, May 19, 2005. http://search.proquest.com.aufric.idm.oclc.org/docview/468672997/D5E7637131CB4A9APQ/58?accounti $\mathrm{d}=4332$.

US House of Representatives, Committee on Armed Services, and Military Forces and Personnel Subcommittee. Women in Combat: Hearing Before the Military Forces and Personnel Subcommittee of the Committee on Armed Services, House of Representatives, One Hundred Third Congress, First Session, Hearing Held May 12, 1993. Washington: US Government Printing Office, 1994.

US House of Representatives, Committee on Armed Services, and Military Personnel and Compensation Subcommittee. Women in the Military: Hearings Before the Military Personnel and Compensation Subcommittee of the Committee on Armed Services, House of Representatives, One Hundredth Congress, First and Second Sessions, Hearings Held October 1, November 19, 1987 and February 4, 1988. Washington: US Government Printing Office, 1988.

. Women in the Military: The Tailhook Affair and the Problem of Sexual Harassment: Report of the Military Personnel and Compensation Subcommittee and Defense Policy Panel of the Committee on Armed Services, House of Representatives, One Hundred Second Congress, Second Session. Washington: US Government Printing Office, 1992.

US House of Representatives, Committee on Armed Services, and Subcommittee on Military Personnel. Women in Service Reviews: Hearing Before the Subcommittee on Military Personnel of the Committee on Armed Services, House of Representatives, One Hundred Thirteenth Congress, First Session, Hearing Held July 24, 2013. US Government Printing Office, 2013. http://purl.fdlp.gov/GPO/gpo40895.

US Senate, and General Accounting Office. Gender Issues Information on DoD's Assignment Policy and Direct Ground Combat Definition: Report to the Ranking Minority Member, Subcommittee on Readiness, Committee on Armed Services, U.S. Senate. Washington, D.C. (P.O. Box 37050, Washington, D.C. 20013): US Government Printing Office, 1998.

Gender Issues Perceptions of Readiness in Selected Units: Report to the Ranking Minority Member, Subcommittee on Readiness and Management Support, Committee on Armed Services, U.S. Senate. Washington, D.C. (P.O. Box 37050, Washington, D.C. 20013): US Government Printing Office, 1999.

Vanden Brook, Tom, and Jim Michaels. "Officials: Panetta Opens Combat Roles to Women." Army Times, January 23, 2013. http://www.armytimes.com/article/20130123/NEWS/301230317/Officials-Panettaopens-combat-roles-women.

Weigley, Russell F. "The American Civil-Military Cultural Gap: A Historical Perspective, Colonial Times to the Present." Soldiers and Civilians: The Civil-Military Gap and American National Security, 2001, 21546.

Weinraub, Bernard. "Pentagon Asks Congress to End Ban on Women in Combat Units Foxholes or Bombers Many Definitions of 'Combat." New York Times. March 4, 1978.

Whitlock, Craig. "Trading Tradition for Tough Leadership." The Washington Post. August 20, 2011, sec. A.

Wiegand, Krista E., and David L. Paletz. "The Elite Media and the Military-Civilian Culture Gap." Armed Forces and Society 27, no. 2 (Winter 2001): 183-204. 
"Women in Combat: Why Rush to Judgment?" The Heritage Foundation, June 14, 1991. http://www.heritage.org/research/reports/1991/06/bg836-women-in-combat-why-rush-to-judgment.

"Women in Military Combat? What It Means for American Culture and Defense." The Heritage Foundation, May 28, 1991. http://www.heritage.org/research/lecture/women-in-military-combat-what-it-means-foramerican-culture-and-defense. 